\title{
The Philosophy of Language Acquisition in Stephen Krashen's Theory based on Multiple Intelligences Classroom
}

\author{
Suci Ramadhanti Febrianii ${ }^{1}$, Wildana Wargadinata ${ }^{2}$, Zainul Arifin ${ }^{3}$ \\ ${ }^{12}$ UIN Maulana Malik Ibrahim Malang, Indonesia \\ ${ }^{3}$ UIN Imam Bonjol Padang, Indonesia
}

Article History:

Received : September 29, 2020

Revised : May 29, 2021

Accepted : May 29, 2021

Published : June 04, 2021

Keywords:

Adequate Language;

Environmental Design;

Sensory Experience.

*Correspondence Address:

Suciramadhantifebriani11@gmail.com

\begin{abstract}
Language acquisition and language learning among scientists tend to be different. This is based on the fact that the language acquisition process is supported unconsciously and is limited to a certain time. Meanwhile, the language learning process can be done consciously and is not limited by time. Through these two arguments, according to Stephen Krashen the acquisition process has certain characteristics. He believes that language acquisition can be obtained in adults. Based on the statement, this study aims to describe and analyze the philosophy that encourages Stephen Krashen to develop a theory of language acquisition through classroom management based on Multiple Intelligences. This study used a qualitative research design with a case study method at SD Plus Al-Kaustar Malang with data collection including observation, interview and documentation study through an analysis technique consisting of three stages; data collection, reduction and conclusion. The results show that the philosophical background built in the theory of Stephen Krashen based on Multiple Intelligences is a collaborative stream of empiricism. This is known through the process of language acquisition which is formed through an adequate language environment carried out by the sensory experience of students with the help of their cognitive thinking processes. These findings indicate that language acquisition can be done through a good environmental design even though it has passed the age limit for first language acquisition.
\end{abstract}

\section{A. INTRODUCTION}

The process of language acquisition and language learning theoretically and practically shows a difference. ${ }^{1}$ It is known that the difference between these two terms determines a meaningful meaning. Experts say that the process of acquiring language in another term known as Language Acquisition (LA) includes 
language acquisition by children naturally. ${ }^{2}$ This happens when a child learns his mother tongue. The process of acquiring naturally acquired language. This is in contrast to the term language learning known as Language Learning (LL), which shows that language is an object of study to be studied consciously and structurally. ${ }^{3}$

Through the difference between the two terms, experts also distinguish between these terms, including several psycholinguists, one of which is Choamsky. He interpreted the theory in his hypothesis called the Innates Hypothesis, which means that every human being is born has a special capacity device for language that other creatures do not have. However, this is different from Stephen Krashen who argues that acquisition of a second language can be obtained naturally like acquisition of a first language.

Stephen Krashen, who is known as a psycholinguist, gave his thoughts and gave the theory of second language acquisition. ${ }^{4}$ According to him, acquisition of a second language can be obtained just like the first language. ${ }^{5}$ Before examining further, the process of acquiring language is language income which refers to natural processes, involving humans to learn language unconsciously. This process is one of the results of the interaction between students and the people around them. In this process, it is students who have an active role in obtaining language from adequate interactions.

Functionally, this process gives an important role to the learner's language. Krashen believes that the process of acquiring language is not absolute only in the first language.

\footnotetext{
1 Wen Lai and Lifang Wei, “A Critical Evaluation of Krashen's Monitor Model," Theory and Practice in Language Studies 9, no. 11 (2019): 1459, https:/ / doi.org/10.17507/tpls.0911.13.

2 Irfan Tosuncuoglu, "Place of Critical Thinking in EFL," International Journal of Higher Education 7, no. 4 (2018): 26-32, https:/ / doi.org/10.5430/ijhe.v7n4p26.

3 Uril Bahruddin and Suci Ramadhanti Febriani, "Implementation of Krashen's Theory in Language Acquisition Stephen", International Journal of Innovation, Creativity and Change 13, no. 8 (2020): 821-31.

4 Stephen D. Krashen, "Formal and Informal Linguistic Environments in Language Acquisition and Language Learning," TESOL Quarterly 10, no. 2 (1976): 157, https://doi.org/10.2307/3585637.

5 Stephen D. Krashen, Principles and Practice in Second Language Acquisition, Review of Educational Research, vol. 33 (University of Southern California, 2009), https://doi.org/10.3102/00346543033001038.
} 
This means that the acquisition of a second language can occur with environmental support. On this basis, the language acquisition put forward by Krashen has a philosophical basis that can build his argument in putting forward the theory of language acquisition. On that basis, fundamental studies related to language acquisition are still practical and in various domains, such as implementation of language acquisition according to Stephen Krashen ${ }^{6}$, models of foreign language acquisition from a psycholinguistic perspective ${ }^{7}$, descriptive analysis of the theory of second language acquisition or historical studies in language acquisition. ${ }^{8}$

Through several previous studies, the study of the philosophical background of language contained in Stephen Krashen's theory of language acquisition is still an urgent study. It aims to analyze how Krashen's theory is constructed into a theory that is used throughout the world. Based on the argument before, this study aims to find out and analyze how the philosophy in Stephen Krashen's theory uses multiple intelligences-based classroom management.

Multiple intelligence-based classroom management has been pioneered by Horward Gardner. ${ }^{9}$ He revealed that each human being has its own uniqueness. ${ }^{10}$ Every human being has an intelligence that is more dominant than the other intelligences. ${ }^{11}$ It can be seen that according to Gardner, intelligence can be seen in 8 different domains. ${ }^{12}$ This can be described in the following figure.

${ }^{6}$ Bahruddin \& Febriani., "Implementation of Krashen' s Theory in Language Acquisition Stephen."

7 Soodeh Hamzehlou Moghadam, Zaidah Zainal, and Mahsa Ghaderpour, "A Review on the Important Role of Vocabulary Knowledge in Reading Comprehension Performance," Procedia - Social and Behavioral Sciences, 2012, https:// doi.org/10.1016/j.sbspro.2012.11.300.

8 Nabaraj, "Second Language Acquisition as a Discipline: A Historical Perspective," NELTA Gandaki II (2004): 55-64. 2003).

9 Howard Gardner, Multiple Intelligences, Kecerdasan Majemuk Teori Dan Praktek (Batam: Interaksara,

10 Charles R. Graham, “Blended Learning Systems: Definition, Current Trends, and Future Directions," in Handbook of Blended Learning: Global Perspectives, Local Designs, 2006.

11 Arifka Mahmudi et al., "Classroom Management and Arabic Learning Process Based on Multiple Intelligences", Arabiyât 6, no. 2 (2019): 222-37. Books, 1999).

12 Howard Gardner, Intelligence Reframe: Multiply Intelligences for 21st Century (New York: Basic 


\begin{tabular}{|c|c|}
\hline Intelligence & Preference \\
\hline Bodily-kinesthetic & $\begin{array}{l}\text { Students enjoy and learn best from activities that use the body and involve movement, such as dance, crafts, } \\
\text { mime, sports, acting and using manipulatives. }\end{array}$ \\
\hline Interpersonal & $\begin{array}{l}\text { Students learn well through interacting with others and prefer team and cooperative learning activities; they } \\
\text { may function as effective leaders and mediators. }\end{array}$ \\
\hline Intrapersonal & $\begin{array}{l}\text { Students have a working understanding of themselves and like individual, introspective, and metacognitive } \\
\text { tasks; they may enjoy working at own pace and setting personal goals. }\end{array}$ \\
\hline Logical-mathematical & $\begin{array}{l}\text { Students learn well through logical or mathematical activities, such as problem solving, experiments, logical } \\
\text { games and puzzles, and using numbers and patterns. }\end{array}$ \\
\hline Musical & $\begin{array}{l}\text { Students understand and learn well through the use of rhythm and melody, tapping and rapping, singing and } \\
\text { listening to music. }\end{array}$ \\
\hline Naturalistic & $\begin{array}{l}\text { Students have an understanding of the environment and patterns in nature; they learn well through outdoor } \\
\text { activities and those that involve interacting with natural and environmental materials and concepts. }\end{array}$ \\
\hline Verbal-linguistic & $\begin{array}{l}\text { Students learn well through language and words; they enjoy reading, writing and speaking, and like to use } \\
\text { language in games, puzzles, and creative activities. }\end{array}$ \\
\hline Visual-spatial & $\begin{array}{l}\text { Students understand and learn easily through the spatial media; they like to learn and communicate visually and } \\
\text { enjoy creating puzzles, maps, designs, 3-D models, and graphic representations. }\end{array}$ \\
\hline
\end{tabular}

Figure 1. Learning Process based on Multiple Intelligences

Through the description in figure 1, it can be seen that the learning process carried out based on multiple intelligences is very diverse. This is an interesting study about the language acquisition process according to Stephen Krashen which is based on multiple intelligences of classroom management.

\section{B. METHODS}

This study used a qualitative research design that aims to explore existing phenomena in detail and systematically. ${ }^{13}$ It used case research method. Basically, observation, interview and documentation are a data collection method. This analysis technique is done by using triangulation analysis techniques. This is done in three systematic steps; data collection, data reduction and conclusions. In addition, researchers also triangulated through data sources, adjusting data through interviews, observation and documentation in detail.

The researchers used the following steps in the process of analyzing data:

${ }^{13}$ Lexy J Moleong, Metodologi Peneleitian Kualitatif (Rosdakarya Offset, 2007). 


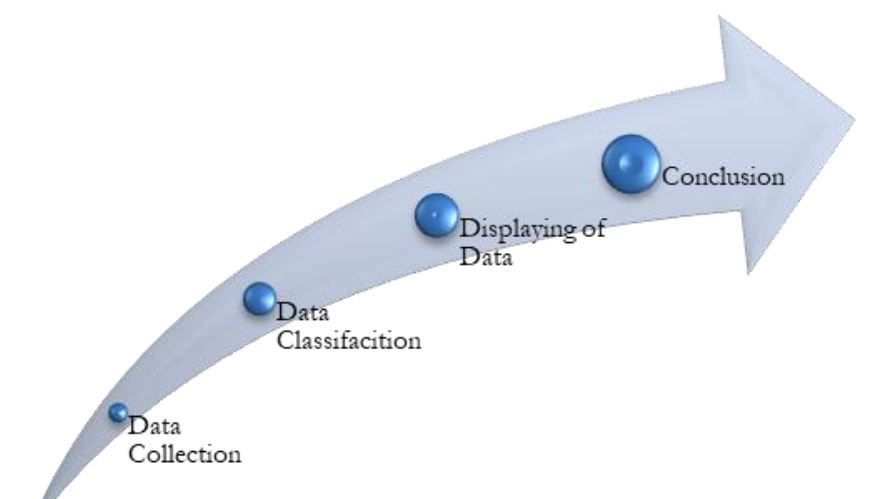

Figure 2. Procedure in analyzing data

This study examined the content in language acquisition according to Stephen Krashen with classroom management based on multiple intelligences. After collecting data, researchers reduced the data by selecting and sorting data that supports the research. Then, the data are verified at this point that the researchers have determined the primary data as important data, and sorted out the unwanted data. With in-depth content analysis techniques, it is expected to be able to answer the philosophy behind Stephen Krashen in developing the theory of language acquisition.

The research used the following design.

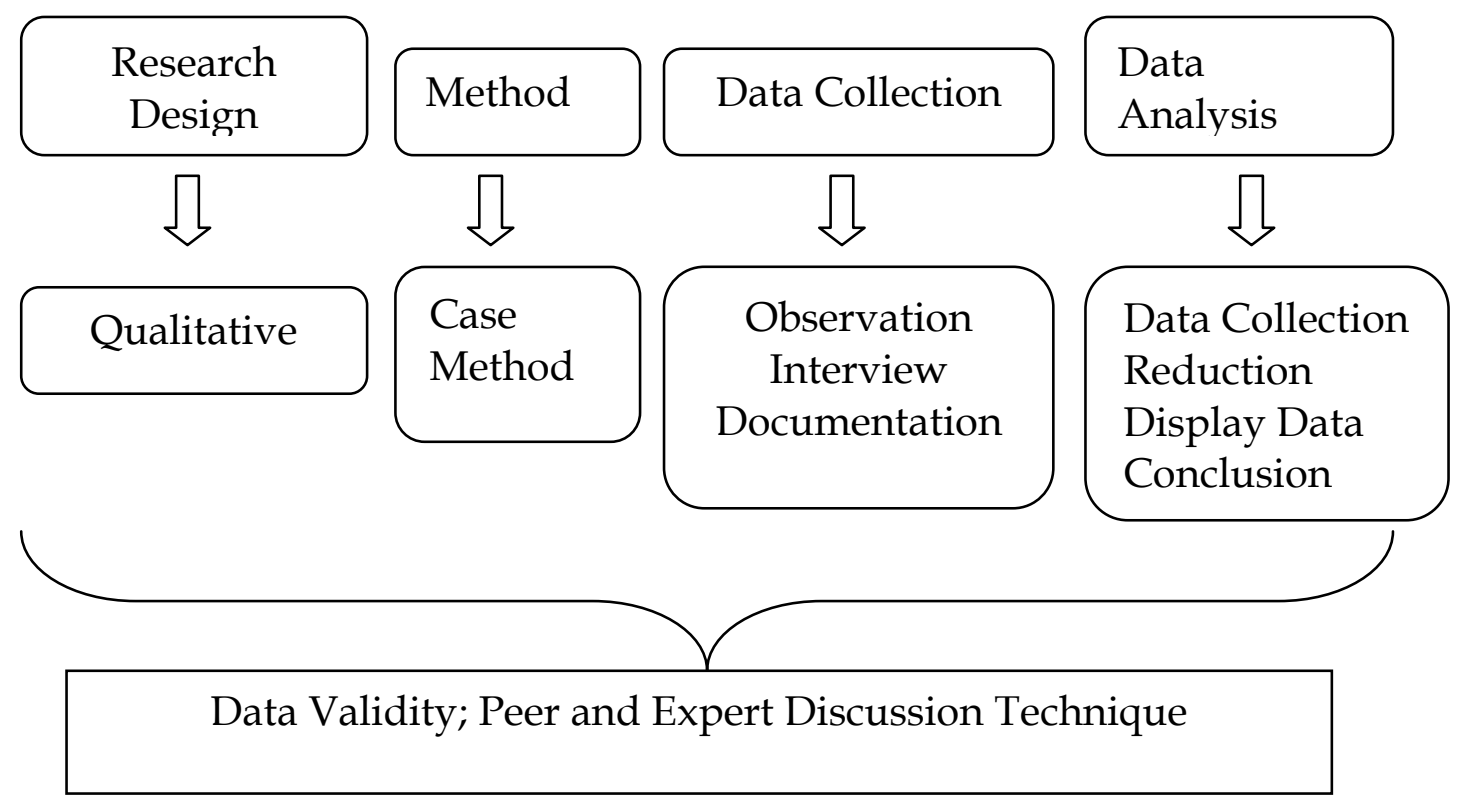

Figure 3. Method 


\section{RESULT AND DISCUSSIONS}

In the classroom management based on multiple intelligences at Al-Kautsar Elementary School implements a learning process based on the Gardner theory. All classes apply a learning policy from grade 3 to grade 5 in elementary school. In each level, the class is divided into 4 study groups. This is applied to the following system.

Table 1. Classifications of Classes

\begin{tabular}{ccc}
\hline No & Class & Classification Class \\
\hline 1 & III-V (A) & Interpersonal-Linguistic class \\
2 & III-V (B) & Mathematically-logically and Intrapersonal class \\
3 & III-V (C) & Visual-Spatial-Music class \\
4 & III-V (D) & Kinesthetic-Natural class
\end{tabular}

Student grouping is not formed according to the eight intelligences in the multiple intelligences, only according to the classification of allied intelligences. This grouping was carried out through end-of-year research in grades 3-5 which involved parents and teachers who were members of the MIR (Multiple Intelligences Research) team. The MIR team at the school consists of 10 teachers. The teacher in charge of the MIR team must take multiple intelligence training and tests.

Classification of students is carried out in several steps. It based on teacher observations of students, interviews with students and parents. Then, there are several tests carried out by students such as doing some of the tasks given by the teacher, such as drawing, singing, arranging numbers, arranging buildings etc.

This aims to determine the classification of students' intelligence according to the psychological conditions in learning. so that learning is fun and meaningful for them through this classification process, learning is easier to direct, so that teachers can choose the right strategy in teaching strategies that greatly determine student learning success, both in terms of cognitive, 
psychomotor or affective. This is because the learning process experienced by students is fun.

Based on the classification of classes, the acquisition of language according to Stephen Krashen can be described by the following explanation. Stephen Krashen suggests 4 categories of theories in language acquisition, one of which is related to the acquisition and learning hypothesis, the monitoring hypothesis, the natural hypothesis, and the input hypothesis.

Krashen used four elements of theory and adopts the process of sensory experience as a medium for acquiring the language. This is in line with the concept of empiricism which states that experience can know the laws of relations between things. In this case, the process of acquiring language acquired through experience is carried out in several stages; observation of phenomena and draw conclusions and experiences that are very complex. ${ }^{14}$ The doctrine that the source of all knowledge must be sought in experience, the view that all ideas are abstractions formed by combining what is experienced, sense experience is the only source of knowledge, and not reason. ${ }^{15}$

Through this, the process of acquiring Stephen Krashen's language can be categorized as containing empirical philosophy. As an illustration of the stages of language acquisition according to Stephen Krashen:

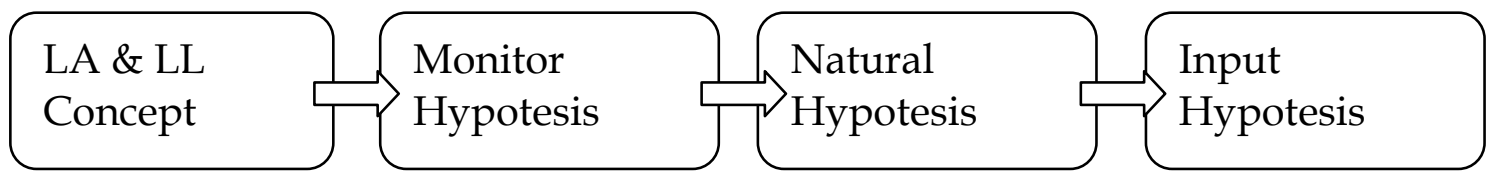

\section{Figure 4. Stephen Krashen's Theory}

Through the following steps, the concepts of language acquisition and language learning have different meanings. Krashen thinks that language acquisition can be implemented in a second language.

14 Bassey Ekpenyong and Ephraim A Ikegbu, "The Language of Philosophy and the Philosophy of Language: A Symbiotic Paradigm," Budapest International Research and Critics Institute-Journal (BIRCIJournal) I, no. 3 (2018): 296-305.

15 Karakas Ali, "An Alanysus of Rationalism in English Language Teaching," International Journal of Educational Spectrum 2, no. 1 (2020): 49-62. 
This is different from other experts who state that the language acquisition process is only obtained through the first language. On that basis, the acquisition of discussion at SDIT Al-Kautsar can be done through a language habituation program on certain days. This can encourage students to acquire Arabic in terms of vocabulary, sound elements or simple sentences through native speakers.

At this step, students used the Arabic language actively in accepting language as a means of communication in the school environment, even though the foreign language used is still standard. So, at this step, students can practice their courage in expressing foreign languages. In the second theory expressed by Krashen, the monitoring hypothesis can be carried out through the process of editing, correcting or correcting the discourse being told. ${ }^{16}$ This shows that learning does not help editing, correcting and correcting grammar, but language monitors the grammar of speech rather than determining fluency and proficiency of speakers. Through the second step, the monitoring process is carried out by the teacher, although students are still in the learning process, monitoring is carried out to correct mistakes made.

In the third step, the natural hypothesis is formed from simple grammar mastery to a more complex stage. This is taught at SDIT Al-Kautsar which develops and adopts a deductive learning process, which means that the language learning process is carried out through easy material to more difficult stages. Through this, the learning adopted is easier so that the process of achieving learning outcomes is maximized. The final step of language acquisition is the effective screening hypothesis. It plays an important variable in language acquisition. This process makes language learners calmer, happy and not even nervous about obtaining information about the new language being learned. ${ }^{17}$

16 Robert Patrick, "Comprehensible Input and Krashen's Theory," Journal of Classics Teaching 20, no. 39 (2019): 37-44, https:// doi.org/10.1017/s2058631019000060.

17 Mark Payne, “Exploring Stephen Krashen's 'i+1' Acquisition Model in the Classroom," Linguistics and Education 22, no. 4 (2011): 419-29, https:/ / doi.org/10.1016/j.linged.2011.07.002. 
As with the teacher's strategy that is adapted to the Multiple Intelligences class-based student learning, the learning process is very enjoyable. So, basically students are playing even though they are doing the learning process unconsciously.

Through language acquisition proposed by Stephen Krashen, language acquisition can occur in second languages. ${ }^{18}$ This is supported by various facilities and infrastructure as well as an adequate environment. Based on some of the facts mentioned, the process of analyzing language philosophy in implementing Stephen Krashens theory through classroom management based on Multiple Intelligences can be described as follows.

Interpersonal-Linguistic class; Students pay attention to vocabulary, they ask questions and the vocabulary was taught yesterday, students look for pairs to play vocabulary guesses, their partners play guesswork, then listen to the teacher's explanation about making sentence patterns, students practice making sentences with predetermined patterns orally, and they are making sentences, other students listen to correct other students' sentence making, students make sentences based on the vocabulary that has been taught in their respective books.

Mathematically-logically, Intrapersonal class; Students pay attention to vocabulary, they drill vocabulary meaningfully, question and answer the vocabulary taught yesterday, students listen to the teacher's explanation about making sentence patterns. Students practice arrange the sentences with predetermined patterns orally, they take turns making these sentences, other students listen to or correct other students' sentence. They arrange sentences based on the vocabulary that has been taught in each books, and they collect the results of their project.

18 Alif Cahya Setiyadi and Mohammad Syam'un Salim, "Pemerolehan Bahasa Kedua Menurut Stephen Krashen," Jurnal At-Ta'dib 8, no. 2 (2013). 
Visual-Spatial-Music class; students sing the vocabulary that has been taught, they ask questions and the vocabulary was taught yesterday, they pay attention to the LCD screen to listen to the explanation of the material, they listen to the teacher's explanation about making sentence patterns, students practice making sentences with predetermined patterns orally, they arrange the sentences, other students listen and correct other students' sentence making, they arrange sentences based on the vocabulary that has been taught in their respective books, students collect the results from their work.

Kinesthetic-Natural class; students show the meaning that has been taught orally, students ask questions and vocabulary that was taught yesterday with classmates, listen to the teacher's explanation about making sentence patterns, students practice making sentences with predetermined patterns orally, students take turns I take turns making sentences Other students listen to and correct other students' sentence making, students make sentences based on the vocabulary that has been taught in their respective books, collect the results of their work. through this design, the philosophy of language adopted is empirical. Empiricism is a school in philosophy which states that all knowledge comes from human experience. Empiricism rejects the notion that humans have carried the nature of knowledge in themselves when they are born. This is supported by several actions that prove that Krashen adopted empirical philosophy. First, knowledge and language acquisition by students through the medium of the senses and direct observation techniques experienced by students. Second, the language acquisition process is supported by an environment that can form habituation in foreign languages, so that it has a positive impact on student speech directly from both teachers and native speakers. Third, in the role of the senses, humans are actually part of things, so that humans can be formed through necessity. 
This is in accordance with the empirical philosophy which adopts that the role of the senses greatly influences humans in acting. It is the same as stated by Skinner, that humans move and do activities cannot be separated from the environment with a stimulus-response scheme from the surrounding environment.

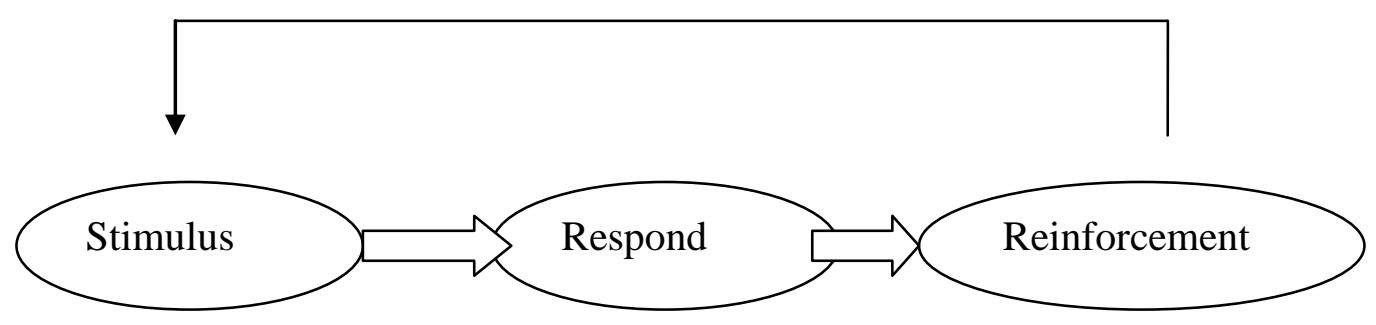

Figure 5. Skinner's Theory

Through Figure 5, it is known that the response stimulus adopted by Skinner's theory is a change in behavior as a result of the first experience. ${ }^{19}$ Experience is the result of capturing human sensory responses that can influence behavior. ${ }^{20}$ The response process carried out to the environment is a learning effort that results. This is supported by class conditions that are in accordance with student intelligence. Thus, the language acquisition process adopted is a natural environmental activity that is formed from the role of teachers, native speakers, curriculum support and conducive classroom management. Based on the findings, this study indicates that language acquisition based on Stephen Krashen's theory is constructed based on empirical philosophy with the facts that have been stated.

\section{CONCLUSIONS}

The process of acquiring language based on Stephen Krashen's theory shows that the adoption of the philosophy used is empirical philosophy. This is

${ }^{19}$ A. Budiman, “Behaviorism in Foreign Language Teaching," English Franca 1, no. 02 (2017): 101-14.

20 Mehdi Dastpak, "A Comparative Study of Vygotsky'S Perspectives on Child Language Development With Nativism and Behaviorism," International Journal of Languages' Education 1, no. Volume 5 Issue 2 (2017): 230-38, https:// doi.org/10.18298/ijlet.1748. 
shown by the active use of the senses towards Arabic acquisition at SDIT AlKautsar. In addition, experiences that are formed through a management-based learning environment in the Multiple Intelligence class can help choose learning strategies that are appropriate to student intelligence. It can be said that language acquisition through the implementation of Stephen Krashen's theory can shape students in active language acquisition. So, second language acquisition can be done with the help of teachers and native speakers who act as people who monitor students' language activities, especially in speaking skills. These findings indicate that the process of language acquisition through Stephen Krashen's theory and classroom management based on multiple intelligences can provide positive outputs on students' language development in terms of cognitive, affective and psychomotor. This study recommends further research with broader and more complex methods and the object of deeper study of the implementation of the philosophical analysis of language developed by experts.

\section{References}

Ali, Karakas. "An Analysis of Rationalism in English Language Teaching." International Journal of Educational Spectrum 2, no. 1 (2020): 49-62.

Alif Cahya Setiyadi, and Mohammad Syam'un Salim. “Pemerolehan Bahasa Kedua Menurut Stephen Krashen." Jurnal At-Ta'dib 8, no. 2 (2013).

Bahruddin, Uril \& Suci Ramadhanti Febriani. “Implementation of Krashen's Theory in Language Acquisition." International Journal of Innovation, Creativity and Change 13, no. 8 (2020): 821-31.

Budiman, A. “Behaviorism in Foreign Language Teaching." English Franca 1, no. 02 (2017): 101-14.

Dastpak, Mehdi. “A Comparative Study of Vygotsky'S Perspectives on Child Language Development With Nativism and Behaviorism." International Journal of Languages' Education 1, no. Volume 5 Issue 2 (2017): 230-38. https://doi.org/10.18298/ijlet.1748. 
Ekpenyong, Bassey, and Ephraim A Ikegbu. “The Language of Philosophy and the Philosophy of Language: A Symbiotic Paradigm." Budapest International Research and Critics Institute-Journal (BIRCI-Journal) I, no. 3 (2018): 296-305.

Graham, Charles R. “Blended Learning Systems: Definition, Current Trends, and Future Directions." In Handbook of Blended Learning: Global Perspectives, Local Designs, 2006.

Howard Gardner. Intelligence Reframe: Multiply Intelligences for 21st Century. New York: Basic Books, 1999.

- - - Multiple Intelligences, Kecerdasan Majemuk Teori Dan Praktek. Batam: Interaksara, 2003.

Krashen, Stephen D. "Formal and Informal Linguistic Environments in Language Acquisition and Language Learning." TESOL Quarterly 10, no. 2 (1976): 157. https:// doi.org/10.2307/3585637.

- - - Principles and Practice in Second Language Acquisition. Review of Educational Research. Vol. 33. University of Southern California, 2009. https://doi.org/10.3102/00346543033001038.

Lai, Wen, and Lifang Wei. "A Critical Evaluation of Krashen's Monitor Model." Theory and Practice in Language Studies 9, no. 11 (2019): 1459. https://doi.org/10.17507/tpls.0911.13.

Lexy J Moleong. Metodologi Peneleitian Kualitatif. Rosdakarya Offset, 2007.

Mahmudi, Arifka, Suci Ramadhanti Febriani, Maidatul Hasanah, Zakiyah Arifa, Universitas Islam, Negeri Maulana, Malik Ibrahim, Kota Malang, and Jawa Timur. “Classroom Management and Arabic Learning Process based on Multiple Intelligences." Arabiyât 6, no. 2 (2019): 222-37.

Moghadam, Soodeh Hamzehlou, Zaidah Zainal, and Mahsa Ghaderpour. "A Review on the Important Role of Vocabulary Knowledge in Reading Comprehension Performance." Procedia - Social and Behavioral Sciences, 2012. https://doi.org/10.1016/j.sbspro.2012.11.300.

Nabaraj. "Second Language Acquisition as a Discipline: A Historical 
Perspective." NELTA Gandaki II (2004): 55-64.

Patrick, Robert. "Comprehensible Input and Krashen's Theory." Journal of $\begin{array}{lllll}\text { Classics } & \text { Teaching } & \text { 20, no. } & \end{array}$ https://doi.org/10.1017/s2058631019000060.

Payne, Mark. “Exploring Stephen Krashen's ' $i+1$ ' Acquisition Model in the Classroom." Linguistics and Education 22, no. 4 (2011): 419-29.

https://doi.org/10.1016/j.linged.2011.07.002.

Tosuncuoglu, Irfan. "Place of Critical Thinking in EFL." International Journal of Higher Education 7, no. 4 (2018): 26-32. https://doi.org/10.5430/ijhe.v7n4p26. 